\title{
Essential nutrients suppress inflammation by modulating key inflammatory gene expression
}

\author{
V. IVANOV, J.CHA, S. IVANOVA, T. KALINOVSKY, M.W. ROOMI, M. RATH and A. NIEDZWIECKI \\ Dr Rath Research Institute, 1260 Memorex Drive, Santa Clara, CA 95050, USA
}

Received August 18, 2008; Accepted September 29, 2008

DOI: 10.3892/ijmm_00000079

\begin{abstract}
We investigated the effects of a nutrient mixture (NM) consisting of ascorbic acid, quercetin, naringenin, hesperetin, tea catechins, lysine, proline, arginine and N-acetyl cysteine on experimental in vivo and in vitro inflammation triggered by bacterial lipopolysaccharide (LPS). BALB/c mice $(n=36)$ were administered NM $(200 \mathrm{mg} / \mathrm{kg} \mathrm{BW})$ or ibuprofen (20 mg/kg BW) for two weeks. Blood plasma, collected three hours after a single intraperitoneal injection with LPS (1 mg/kg BW), was analyzed with 14 cytokine microarray. LPS inflammatory effects were analyzed in human U937 macrophages by cytokine release, cyclooxygenase (COX) enzymatic activity, COX protein expression (Western blot analysis), specific mRNA levels (RT-PCR), and nuclear factor $\kappa \beta(N F \kappa \beta)$ activation (phosphorylated p65 immunoassay). Nutrient supplementation in mice altered the LPSinduced cytokine response in a manner similar to ibuprofen $(\mathrm{r}=0.4157, \mathrm{p}=0.139)$. Cytokine response to LPS in cultured macrophages was similar to the in vivo study $(\mathrm{r}=0.718$, $\mathrm{p}=0.023)$. NM inhibited COX-2 enzymatic activity, and COX-2 and pro-inflammatory cytokine protein expression levels were downregulated by NM at the transcription level complementing a blockade in NFK $B$ activation. NM demonstrated strong beneficial effects on the experimental inflammation by targeting multiple responsible mechanisms in the complex process involved in the inflammatory reaction to pathogens.
\end{abstract}

\section{Introduction}

Inflammation is a complex biological response of the mammalian immune system to harmful stimuli, such as pathogens and damaged cells. Inflammation is characterized initially by an increased movement of plasma and leukocytes to the injured tissues followed by a cascade of biochemical events involving the local vascular system, the immune

Correspondence to: Dr Aleksandra Niedzwiecki, Dr Rath Research Institute, 1260 Memorex Drive, Santa Clara, CA 95050, USA

E-mail: author@drrath.com

Key words: inflammation, cytokine, macrophage U937, BALB/c mice system and various cells within the injured tissue. When prolonged, there is a progressive shift in cell type at the site of inflammation, and simultaneous destruction and healing of the tissue occurs. Chronic inflammation accompanies and aggravates the progression of all modern human chronic pathological conditions. For example, in atherosclerosis, the release of cytokines and chemokines from activated immunecompetent cells plays a crucial role in the progression of the pathology (1). The discovery of endogenous molecules involved in the inflammatory process, such as inflammatory cytokines, provides targets for controlling inflammation. Several epidemiological studies have postulated an association beween infectious agents such as gram negative bacteria and chronic cardiovascular disease. Bacterial lipopolysaccharide (LPS) induction of cytokines in carotid lesions resulted in increased protein levels of interleukin-1ß (IL-1ß), IL-6, IL-8, IL-10 and tumor necrosis factor $\alpha(\mathrm{TNF} \alpha)(2)$.

Inflammation involves the sequential activation of signalling pathways leading to the production of both proand anti-inflammatory mediators. The transcription factor nuclear factor $\kappa \beta(N F \kappa \beta)$ is thought to play a central role in the induction of pro-inflammatory gene expression and has attracted interest as a new target for the treatment of inflammatory disease. Recognition of $N F \kappa \beta$ as a critical switch that activates inflammation has profound implication for therapeutic manipulation of regulatory circuits controlling the inflammatory process, regardless of its causes (3-6). Due to these factors, emerging research has focused on developing medications that target potential inhibitors of NFKß activation.

Growing evidence indicates the beneficial role of proper nutrition in controlling inflammation, including its inhibitory effects on mediators of inflammation, such as cytokines. We investigated the effects of a combination of selected essential nutrients in experimental inflammation in vivo and in vitro and the molecular mechanisms involved. The nutrients selected for this investigation: green tea catechins, citrus flavonoids, ascorbic acid and amino acids were chosen due to their known anti-inflammatory activities. For example, green tea has been recognized to have anti-inflammatory effects by suppressing inflammation mediators as IL-1ß and attenuation of transcription factor NFKß (7). Quercetin, known as an anti-inflammatory/anti-allergy natural remedy, stabilizes mast cell membranes and prevents the release of histamine and other inflammatory agents in the body; it has been shown to reduce IL- 6 and TNF $\alpha$ in LPS-challenged murine macrophages (8). Another study found that administration of a citrus flavonoid hesperidin (HP) to mice before LPS 
challenge significantly reduced tumor necrosis factor $\alpha$ $(\mathrm{TNF} \alpha)$ production in a dose-dependent manner (9). Ascorbic acid has been shown to enhance inhibition of PGE2 release in primary rat microglia by acetylsalicylic acid (10). The citrus flavanone naringenin also exhibits anti-inflammatory properties by protecting mice against endotoxin shock induced by Salmonella infection and suppressing $\mathrm{TNF} \alpha$ and normalizing the activated states of blood coagulation factors such as prothrombin time, fibrinogen concentration and platelet numbers caused by infection (11). Antioxidants $\mathrm{N}$-acetyl cysteine and arginine also have been shown to increase nitric oxide stores (12-14) which has a vasodilatory effect on microcirculation, enhancing local oxygen delivery to peripheral tissue.

\section{Materials and methods}

Materials. Reagents were supplied by Sigma-Aldrich (St. Louis, MO) unless specified differently. Green tea extract (40\% epigallocatechin gallate) and other water-soluble nutrients for experimental mixture testing were supplied by Vitatech (Hayward, CA) as a pre-mixed powder. Stock solutions of hydrophobic flavonoids (quercetin, hesperitin and naringenin) were prepared in $100 \%$ ethanol and stored at $-20^{\circ} \mathrm{C}$ over the duration of the experiment. The tested nutrient mixture was prepared daily as $20 \mathrm{mg} / \mathrm{ml}$ stock solution by dissolving water-soluble components in Dulbecco's phosphate-buffered saline (PBS, Life Technologies) followed by addition of flavonoids dissolved in ethanol. NM solution was sterilized by filtration through a $0.2-\mu \mathrm{m}$ filter. NM stock solution contained $18 \mu \mathrm{mol} / \mathrm{l}$ ascorbic acid, $22 \mu \mathrm{mol} / 1 \mathrm{~L}-1 y s i n e$, $26 \mu \mathrm{mol} / 1 \mathrm{~L}$-proline, $10 \mu \mathrm{mol} / 1 \mathrm{~L}$-arginine, $5 \mu \mathrm{mol} / 1 \mathrm{~N}$-acetyl L-cysteine, $0.12 \mu \mathrm{mol} / 1 \mathrm{~L}-$ selenomethionine, $3 \mu \mathrm{mol} / 1$ epigallocatechin gallate (EGCG), $3 \mu \mathrm{mol} / 1$ quercetin, $3 \mu \mathrm{mol} / 1$ naringenin and $3 \mu \mathrm{mol} / 1$ hesperitin.

Animals. Male BALB/c mice $(n=36)$ at 5 weeks of age and weighing between 18 and $20 \mathrm{~g}$ were purchased from Simonson Laboratories (Gilroy, CA). Upon arrival and throughout the experiments, animals were maintained in microisolator cages under pathogen-free conditions, caged by a number of five, or less where appropriate, in a climate-controlled environment set to $22^{\circ} \mathrm{C}$ and on a 12 -h light/12-h dark cycle. Animals had constant access to drinking water and regular rodent chow supplied ad libitum. All animals were cared for in accordance with institutional guidelines for the care and use of experimental animals. The experimental protocols were approved by the Institute Animal Care Committee in accordance with USDA regulations. Animals were used for experiments after a weeklong acclimatization period.

\section{Experimental design}

Effect of ibuprofen or nutrient mixture supplementation on blood plasma inflammatory cytokines in the BALB/c mice challenged with bacterial lipopolysaccharide. Male 6-weekold BALB/c mice were randomly assigned to one of four groups and received daily intraperitoneal (i.p.) supplementation for nine consecutive days with one day interruption in the middle of the supplementation sequence as follows: vehicle (Group 1, n=7 and Group 2, n=10), $20 \mathrm{mg}$ ibuprofen (IBU) per $\mathrm{kg}$ of body weight (Group 3, n=7), or $200 \mathrm{mg}$ of the nutrient mixture (NM) per kg body weight (Group 4, n=12) in $250 \mu \mathrm{l} \mathrm{PBS} / 10 \%$ ethanol. Twenty-four hours after the last i.p. supplement, mice were challenged with i.p. injection of $1 \mathrm{mg}$ LPS per $\mathrm{kg}$ of body weight (Groups 2, 3 and 4) in $250 \mu \mathrm{l}$ PBS or PBS only (Group 1). Three hours after LPS injection, animals were sacrificed by cervical dislocation under isoflurane anesthesia and weighed. Blood was collected by cardiac puncture into EDTA solution, and the resulting plasma samples were stored at $-70^{\circ} \mathrm{C}$ until analyzed. Livers and kidneys were collected and weighed. Slices of tissues were fixed in $10 \%$ buffered formalin and histologically evaluated. No signs of toxicity were observed in any liver or kidney sample obtained from the groups. Animal body weights at sacrifice did not differ significantly for either group (data not shown).

Human U937 macrophage experiments. The human monocytic U937 cell line was purchased from ATCC and propagated suspended in RPMI-1640 medium supplemented with 5\% fetal bovine serum (FBS; both from ATCC). For experiments, U937 cells were seeded into the wells of 48- or 6-well plates at the density of $1 \times 10^{6}$ cells $/ \mathrm{ml}$ in 0.5 or $3 \mathrm{ml}$ of growth medium, respectively. Monocyte to macrophage differentiation was initiated by growth medium supplementation with $40 \mathrm{nM}$ phorbol 12-myristate 13-acetate (PMA). After a 48-h incubation adhered cell layers were gently washed twice with RPMI-1640 plain medium to remove floating cells and supplemented with $0.1 \%$ BSA/RPMI-1640 containing $40 \mathrm{nM}$ PMA and other additions, as indicated, for another 24-h incubation. The conditioned cell culture medium was collected, separated from floating cells by centrifugation and stored at $-80^{\circ} \mathrm{C}$ until analyzed. Cell availability in 48 -well plates was assayed with MTT assay. Adhered macrophage cell layers were washed twice with PBS and incubated with $0.5 \mathrm{mg} / \mathrm{ml}$ MTT in RPMI-1640 for $4 \mathrm{~h}$. Optical density was measured at $550 \mathrm{~nm}$ after extracting cell layers with DMSO. No statistically significant loss of cell availability was detected under any experimental condition presented.

Cytotoxic effects of the tested compounds on suspended cultures of monocytic U937 cells were assayed with the Trypan Blue exclusion test as described in the legend for Fig. 1. Cell layers in 6-well plates were washed twice with PBS and scraped out in corresponding lysing buffer for later protein content assay (BCA assay, Pierce Biotechnology, Inc.). Western blot assay, real-time PCR assay or NFkß activation assay was performed as described below.

\section{Biochemical assays.}

Cytokine assay. Plasma samples and conditioned medium samples from the U937 macrophage experiment were assayed for mouse and human cytokine panels, respectively, using cytokine microarray service at Allied Biotech, Inc. (Ijamsville, MD). IL-10 levels in conditioned cell culture media were evaluated by immunoassay (R\&D Systems) according to the manufacturer's protocol.

Prostaglandin E2 (PGE2) assay. Conditioned medium samples from U937 macrophage experiments were evaluated for PGE2 content by immunoassay (R\&D Systems) according to the manufacturer's protocol. 
COX enzymatic activity assay. Adhered U937 macrophage cultures were activated with $10 \mu \mathrm{g} / \mathrm{ml}$ LPS in $0.1 \% \mathrm{BSA} /$ RPMI-1640 containing $40 \mathrm{nM}$ PMA for $24 \mathrm{~h}$ or without LPS. Cell cultures were washed of LPS and preincubated with 10 or $100 \mu \mathrm{g} / \mathrm{ml} \mathrm{NM}$ in the presence or absence of $1 \mu \mathrm{M}$ ibuprofen for $15 \mathrm{~min}$ in $0.1 \% \mathrm{BSA} / \mathrm{RPMI}-1640$. Arachidonic acid was added to the same media at a $15-\mu \mathrm{M}$ final concentration for another $15 \mathrm{~min}$ at $37^{\circ} \mathrm{C}$, and PGE2 formation in conditioned media was assayed as above.

COX-1 and COX-2 Western blot assay. Adhered U937 macrophage cultures were incubated in 6-well plates with or without $10 \mu \mathrm{g} / \mathrm{ml}$ LPS in BSA/RPMI-1640 supplemented with $2 \mu \mathrm{g} / \mathrm{ml}$ ibuprofen or $10 \mu \mathrm{g} / \mathrm{ml}$ nutrient mixture or not for $24 \mathrm{~h}$. Cell plates were placed on ice, and the cells were gently washed once with ice-cold PBS. Ice-cold radioimmunoprecipitation (RIPA) buffer $(200 \mu \mathrm{l})(50 \mathrm{mM}$ Tris- $\mathrm{HCl}$, $\mathrm{pH} 7.5,1 \%$ Triton X-100, 1.0\% Na-deoxycholate, $150 \mathrm{mM}$ $\mathrm{NaCl}, 2 \mathrm{mM}$ EDTA) (Teknova) with $1 \mathrm{mM}$ activated sodium orthovanadate, and 1X Complete Mini Protease Inhibitor Cocktail tablets (Roche) were added to each well. Cells were detached using a plastic cell scraper. Lysis buffer and cells were collected in 1.5-ml Eppendorf tubes and allowed to lyse for $15 \mathrm{~min}$ on ice with orbital rotation. Lysates were cleared by spinning at $16,000 \mathrm{rpm}$ on a microcentrifuge for $15 \mathrm{~min}$ at $4^{\circ} \mathrm{C}$. Supernatants were retrieved, and insoluble cell debris pellets discarded. Lysates were diluted 10x before protein determination with the BCA method performed in 96-well plates and read on an ELISA reader. Samples were adjusted for maximum equal protein loading per lane on 10-well 4-12\% Bis-Tris gels (Invitrogen) before running under reducing conditions with $10 \mathrm{X}$ reducing reagent (Invitrogen). A protein size standard was included. Proteins were transferred to Invitrolon PVDF $0.45-\mu \mathrm{M}$ pore membranes using the Xcell II Blot Module (Invitrogen) overnight at $4^{\circ} \mathrm{C}$. Membranes were blocked for non-specific binding in 5\% immunoblotting skim milk (Bio-Rad) in 1X TTBS (1X TBS, $0.1 \%$ Tween-20) for $1 \mathrm{~h}$ at room temperature with orbital rotation. TBS $10 \mathrm{X}$ (24.2 $\mathrm{g}$ Tris base, $80 \mathrm{~g} \mathrm{NaCl}, 1$ liter distilled water, $\mathrm{pH} 7.6$ with $\mathrm{HCl}$ ) was prepared in advance. TTBS milk 5\% was discarded after blocking for non-specific binding. Primary rabbit polyclonal anti-human COX-2 antibody (Rockland, \#100-401-226) was added at a dilution of 1:10,000 in 5\% TTBS milk. Membranes were incubated at room temperature for $2 \mathrm{~h}$ with gentle orbital rotation. Primary antibody was discarded, and membranes were washed with gentle orbital rotation using three changes of excess TTBS. Secondary goat anti-rabbit-HRP (Rockland) at a dilution of 1:200,000 in 5\% milk TTBS was added, and the membranes were incubated for $1 \mathrm{~h}$ at room temperature with gentle orbital rotation. Membranes were washed as above before developing with SuperSignal West Femto Maximum Sensitivity Substrate (Pierce Biotechnology, Inc.) and exposed to ECL Hyperfilm (Amersham). Developed Western blots were digitally scanned before using software densitometry (Scion Image) to quantitate protein band intensity. Membranes were stripped of antibodies using Restore Western Blot Stripping Buffer (Pierce Biotechnology, Inc.) before reprobing as above with primary rabbit polyclonal $\beta$-actin antibody (Cell Signaling Technology, \#4967) at 1:20,000 and secondary goat anti-rabbit HRP antibody (Rockland) at 1:200,000. For COX-1 Western blotting, COX-1 monoclonal antibody (Cayman Chemical \#160110) was used at a dilution 1:2000 in 5\% milk TTBS and secondary goat anti-mouse IgG-HRP was used at a dilution of 1:200,000 (Pierce Biotechnology, Inc.). Membranes were developed and scanned as before.

Real-time PCR. A duplicate set of plates from the Western blot experiments were used to generate total RNA. Poly-A mRNA was isolated using TurboCapture 96 mRNA Kit (Qiagen). A sample of eluted mRNA was quantitated for concentration using the Quant-iT Ribogreen ${ }^{\circledR}$ RNA Reagent and Kit (Molecular Probes) and the remainder was stored at $-70^{\circ} \mathrm{C}$ until first-strand synthesis. Complementary DNA was generated using between 10 to $30 \mathrm{ng}$ of template mRNA per volume reaction with the Quantitect ${ }^{\circledR}$ Reverse Transcription Kit (Qiagen), which eliminates false positive RT-PCR signals created by genomic DNA contamination. For real-time PCR, the 7900HT 384-well machine was used with TaqMan ${ }^{\circledR}$ FAM-NFQ pre-made human probes purchased from Applied Biosystems. TaqMan ${ }^{\circledR}$ Gene Expression Assays were chosen for their robust primer design. Cox-2 (PTGS2) probe Hs00153133_m1, IL-1ß probe Hs00174097_m1, IL-6 probe Hs00174131_m1, IL-12b probe Hs00233688_m1, monocyte chemoattractant protein-1 (MCP-1/CCL-2) probe Hs00234140_m1, TNF- $\alpha$ probe Hs00174128_m1 and B-actin probe Hs99999903_m1 were purchased from Applied Biosystems. Reactions were performed in $20 \mu 1$ with TaqMan ${ }^{\circledR}$ Universal Master Mix (Applied Biosystems). Log dilutions of cDNA were run until the optimal dilution was achieved for all genes within the linear range without data artifacts. Triplicate samples were run for each experimental condition for all six genes of interest and the housekeeping gene, $ß$-actin. The machine was run at $50^{\circ} \mathrm{C}$ for $2 \mathrm{~min}, 95^{\circ} \mathrm{C}$ for $10 \mathrm{~min}, 95^{\circ} \mathrm{C}$ for $15 \mathrm{sec}$, and $60^{\circ} \mathrm{C}$ for $1 \mathrm{~min}$ for 40 cycles with ramp rate at $100 \%$, and data were collected in the third stage. Relative expression of each gene was calculated using the classical $2^{\wedge}$ (Gene of Interest-Housekeeping gene) equation with baseline noise subtracted from amplification plots.

Nuclear factor $\kappa \beta$ assay. Levels of phosphorylated p65 were determined in cell protein extracts by ELISA (Cell Signaling Technology, Danvers, MA) according to the manufacturer's protocol. Values were related to cell protein content and expressed as a percentage of LPS-only control.

Statistical analysis. All in vitro experiments were performed at least twice in triplicates. Results are averages \pm SD from representative experiments. Statistical analysis was performed using MedCalc software for correlations (The Netherlands). Differences between treatments were accepted as significant at p-values $<0.05$ in the two-tailed Student's t-test using Microsoft Excel.

\section{Results}

Effect of nutrient mixture supplementation on blood plasma inflammatory cytokines in the BALB/c mice challenged with bacterial lipopolysaccharide. Supplementation with the nutrient mixture significantly reduced overexpression of blood 
Table I. Inflammatory cytokine levels in mouse blood plasma.

\begin{tabular}{|c|c|c|c|c|c|c|}
\hline \multirow[t]{2}{*}{ Cytokines } & \multirow{2}{*}{$\begin{array}{l}\text { Group } 1 \\
\text { Control }\end{array}$} & \multirow{2}{*}{$\begin{array}{c}\text { Group } 2 \\
\text { LPS }\end{array}$} & \multicolumn{2}{|c|}{ Group 3} & \multicolumn{2}{|c|}{ Group 4} \\
\hline & & & IBU+LPS & (\% of LPS) & $\mathrm{NM}+\mathrm{LPS}$ & \% of LPS) \\
\hline $\mathrm{IL}-1 \beta^{\mathrm{a}}$ & $2.9 \pm 1.4$ & $60.0 \pm 18.4^{\mathrm{c}}$ & $56.4 \pm 31.0^{c}$ & (94) & $96.0 \pm 52.3^{\mathrm{c}}$ & $(160)$ \\
\hline IL-2 ${ }^{\mathrm{a}}$ & $9.9 \pm 4.3$ & $10.8 \pm 1.4$ & $13.3 \pm 4.2$ & (123) & $14.0 \pm 3.6$ & (130) \\
\hline IL-4a & $10.2 \pm 5.1$ & $11.3 \pm 6.0$ & $24.6 \pm 11.4^{\mathrm{c}, \mathrm{d}}$ & (217) & $22.1 \pm 6.5^{\mathrm{c}, \mathrm{d}}$ & (195) \\
\hline $\mathrm{IL}-5^{\mathrm{a}}$ & $6.4 \pm 5.5$ & $4.7 \pm 4.6$ & $5.4 \pm 2.6$ & (113) & $14.6 \pm 7.4^{\mathrm{c}, \mathrm{d}}$ & (307) \\
\hline IL-6 ${ }^{\mathrm{b}}$ & $0.005 \pm 0.002$ & $92.0 \pm 15.5^{\mathrm{c}}$ & $61.0 \pm 37.8^{\mathrm{c}}$ & (66) & $38.6 \pm 25.6^{\mathrm{c}, \mathrm{d}}$ & (42) \\
\hline IL-10 & $25.0 \pm 4.2$ & $666.8 \pm 369.0^{c}$ & $412.1 \pm 367.9^{c}$ & (62) & $588.9 \pm 453.8^{c}$ & (88) \\
\hline IL-12p40 & $0.33 \pm 0.05$ & $12.3 \pm 6.4^{\mathrm{c}}$ & $11.7 \pm 9.2^{\mathrm{c}}$ & (94) & $3.6 \pm 1.9^{\mathrm{c}, \mathrm{d}}$ & (29) \\
\hline IL-12p70 & $2.5 \pm 1.2$ & $15.3 \pm 8.3^{\mathrm{c}}$ & $20.2 \pm 19.3$ & (132) & $11.0 \pm 10.7^{\mathrm{c}}$ & (72) \\
\hline IL-13 ${ }^{\mathrm{a}}$ & $19.8 \pm 2.8$ & $22.5 \pm 5.4$ & $25.2 \pm 9.2$ & (112) & $44.1 \pm 17.6^{\mathrm{c}, \mathrm{d}}$ & (196) \\
\hline GM-CSF & $0.4 \pm 0.1$ & $18.7 \pm 11.8^{\mathrm{c}}$ & $9.2 \pm 7.6^{c}$ & (49) & $12.4 \pm 8.1^{\mathrm{c}}$ & (66) \\
\hline VEGFa $^{a}$ & $409.9 \pm 81.2$ & $430.2 \pm 144.1$ & $444.1 \pm 156.6$ & (103) & $749.6 \pm 274.8^{\mathrm{c}, \mathrm{d}}$ & (174) \\
\hline $\mathrm{IFN}-\gamma^{\mathrm{a}}$ & $14.1 \pm 6.2$ & $11.3 \pm 6.1$ & $11.5 \pm 6.1$ & $(102)$ & $36.3 \pm 15.8^{\mathrm{c}, \mathrm{d}}$ & $(322)$ \\
\hline $\mathrm{TNF} \alpha^{\mathrm{a}}$ & $128.9 \pm 30.7$ & $293.9 \pm 77.7^{\mathrm{c}}$ & $240.5 \pm 85.3^{c}$ & (82) & $486.9 \pm 192.0^{\mathrm{c}, \mathrm{d}}$ & (166) \\
\hline MCP-1 ${ }^{\mathrm{b}}$ & $0.05 \pm 0.01$ & $121.6 \pm 61.9^{c}$ & $68.9 \pm 66.6^{c}$ & (57) & $16.8 \pm 15.6^{\mathrm{c}, \mathrm{d}}$ & (14) \\
\hline
\end{tabular}

${ }^{\mathrm{a}} \mathrm{pg} / \mathrm{ml},{ }^{\mathrm{b}} \mathrm{ng} / \mathrm{ml} ;{ }^{\mathrm{c}} \mathrm{p}<0.05$ versus control, ${ }^{\mathrm{d}} \mathrm{p}<0.05$ versus LPS treatment. IL, interleukin; GM-CSF, granulocyte macrophage colony stimulating factor; VEGF, vascular endothelial growth factor; IFN- $\gamma$, interferon- $\gamma$; TNF $\alpha$, tumor necrosis factor $\alpha$; MCP-1, monocyte chemoattractant protein-1. Male 6-week-old BALB/c mice received daily i.p. supplementation for nine days with vehicle (Group 1, $\mathrm{n}=7$ and $\mathrm{Group} 2, \mathrm{n}=10$ ), $0.5 \mathrm{mg}$ ibuprofen (IBU) (Group 3, $\mathrm{n}=7$ ), or $5 \mathrm{mg}$ of the nutrient mixture (NM) (Group 4, n=12). Twenty-four hours after the last administered supplement, mice were challenged with i.p. injection of $25 \mu \mathrm{g}$ LPS (Groups 2, 3 and 4) or PBS only (Group 1). After 3 h, animals were sacrificed, and the blood plasma cytokine level was determined with mouse cytokine microarray assay. Correlation analysis for IBU and NM treatments: correlation coefficient $r=0.4157, \mathrm{p}=0.1393$.

plasma inflammatory cytokines in the model of acute systemic inflammation in mice challenged with bacterial lipopolysaccharide. Two-week supplementation with $250 \mathrm{mg}$ $\mathrm{NM} / \mathrm{kg}$ body weight prior to LPS challenge provided significantly greater protection than did supplementation with ibuprofen, as shown in Table I. Induction of IL-6 and monocyte chemoattractant protein-1, two cytokines particularly responsive to LPS challenge, was reduced in the NMsupplemented animals by $58(\mathrm{p}=0.03)$ and $86 \%(\mathrm{p}=0.04)$, respectively. Corresponding reduction in the ibuprofen group was 34 and $43 \%$, which did not reach statistical significance.

In analyzing the correlation for the percentages of LPS changes for IBU and NM treatment in this animal experiment, the correlation coefficient $r$ was found to be 0.4157 with a significance level $\mathrm{p}=0.1393$. Thus, the correlation between effects of these two treatments in the animal model of systemic inflammation was still positive but did not reach statistical significance.

Notable differences in cytokine levels were observed with the two treatments. IL-1 $\beta$ and TNF $\alpha$ were slightly decreased by IBU ( 94.0 and $81.2 \%$ of LPS group values, respectively), but increased by NM (160.0 and $165.7 \%$ of LPS group values, respectively). IL-12p70 was increased by IBU (132.0\% of LPS) but decreased by NM (71.9\% of LPS). Inhibitory effects on cytokine upregulation by LPS were more pronounced for NM than for IBU for the following cytokines: IL-6, IL-12p40 and MCP-1, but less pronounced for IL-10 and granulocytemacrophage colony-stimulating factor (GM-CSF). Stimulatory effects on cytokine upregulation by LPS were about equally expressed for NM and IBU for IL-2 and IL-4. Stimulatory effects on cytokine upregulation by LPS were more pronounced for NM than for IBU for IL-5 and IL-13. Interferon $\gamma($ IFN- $\gamma$ ) and vascular endothelial growth factor (VEGF) were stimulated by NM, but were not affected by IBU.

Effect of NM or ibuprofen on human U937 monocyte viability. In order to address possible mechanisms involved in antiinflammatory effects of the nutrient mixture, animal studies were compared to in vitro experimental models of human cultured U937 monocyte/macrophages. The nutrient mixture was not toxic to human U937 monocytes, as shown in Fig. 1. LD50 for ibuprofen was $0.3 \mathrm{mg} / \mathrm{ml}$ and for $\mathrm{NM},>4 \mathrm{mg} / \mathrm{ml}$.

Effect of the nutrient mixture and ibuprofen on cytokine secretion of human adhered U937 macrophages stimulated with bacterial LPS. Relative cytokine response to LPS challenge in the mouse model varied from the human macrophage cell model, as shown in Table III. Common cytokines in mouse and human panels numbered 11 and included: IL-1ß, IL-2, IL-4, IL-5, IL-6, IL-10, IL-12p40, IL$12 \mathrm{p} 70, \mathrm{IL}-13, \mathrm{IFN}-\gamma$ and TNF $\alpha$. Comparison of the changes in cytokine release after inflammatory stimulation in in vivo and in vitro experimental models resulted in a Spearman's coefficient of rank correlation of 0.718 , with a significance level of $\mathrm{p}=0.0231$. Thus, a strong, positive correlation exists between these two models and is statistically significant. This validates the use of the cultured macrophage model to address mechanisms involved in the animal model of systemic 


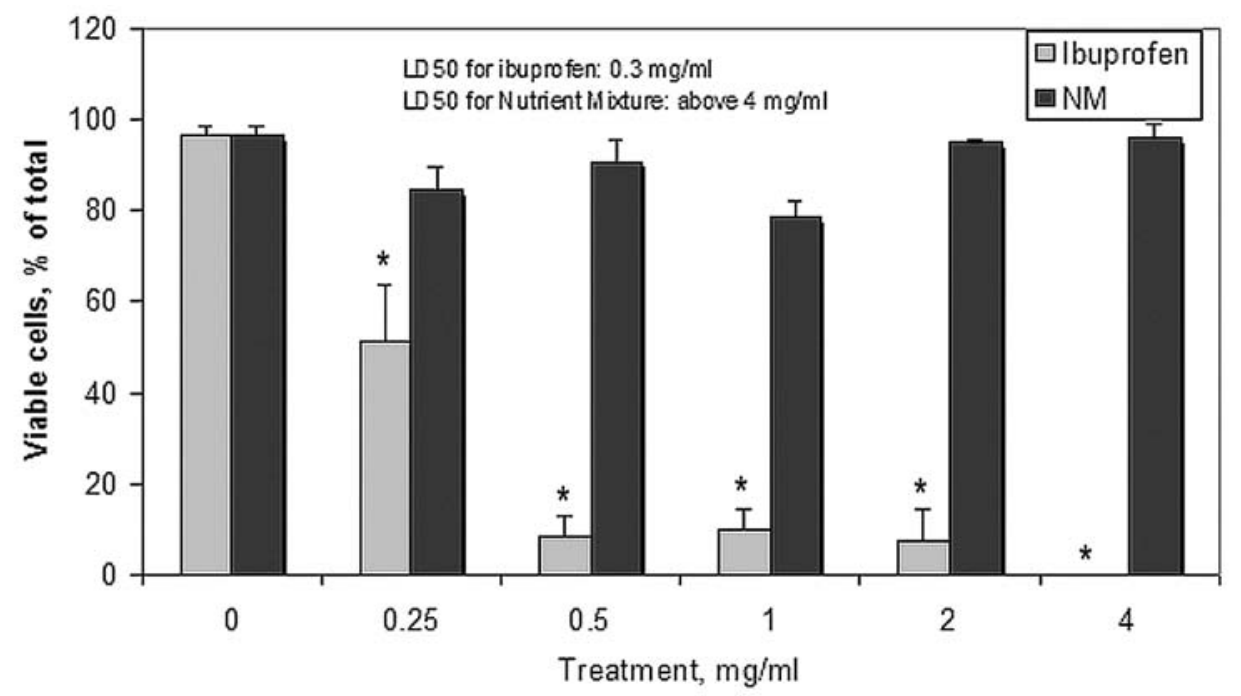

Figure 1. Cytotoxic effects of the nutrient mixture (NM) and ibuprofen (IBU) on human U937 monocytes. Suspended cultures ( $\mathrm{n}=3$ ) of human U937 monocytes were supplemented with the tested compounds for $24 \mathrm{~h}$ in $0.1 \%$ BSA/RPMI-1640. Live cells were counted with the trypan blue exclusion test. LD50 was $0.3 \mathrm{mg} / \mathrm{ml}$ and $>4 \mathrm{mg} / \mathrm{ml}$ for IBU and $\mathrm{NM}$, respectively. ${ }^{*} \mathrm{p}<0.05$ with respect to non-treated control.

Table II. Cytokine secretion by human U937 differentiated macrophages in response to stimulation with LPS.

\begin{tabular}{|c|c|c|c|c|c|c|}
\hline Cytokine & Control & LPS & IBU+LPS & (\% of LPS) & NM+LPS & (\% of LPS) \\
\hline $\mathrm{IL}-1 \beta^{\mathrm{a}}$ & $1.1 \pm 0.1$ & $24.8 \pm 2.7^{\mathrm{c}}$ & $23.8 \pm 1.9^{c}$ & (96) & $4.3 \pm 1.4^{\mathrm{c}, \mathrm{d}}$ & (17) \\
\hline IL- $2^{\mathrm{b}}$ & $1.02 \pm 0.42$ & $3.41 \pm 0.84^{\mathrm{c}}$ & $2.69 \pm 0.15$ & $(79)^{\mathrm{c}}$ & $1.34 \pm 0.18^{\mathrm{d}}$ & (39) \\
\hline IL-4 ${ }^{\mathrm{a}}$ & $0.97 \pm 0.32$ & $3.49 \pm 0.62^{\mathrm{c}}$ & $2.36 \pm 0.27$ & $(68)^{\mathrm{c}, \mathrm{d}}$ & $0.70 \pm 0.29$ & $(20)^{\mathrm{d}}$ \\
\hline IL- $5^{\mathrm{b}}$ & $<50$ & $<50$ & $<50$ & & $<50$ & \\
\hline IL-6 ${ }^{\mathrm{a}}$ & $0.15 \pm 0.02$ & $2.86 \pm 0.36^{\mathrm{c}}$ & $2.28 \pm 0.25$ & $(80)^{\mathrm{c}}$ & $1.39 \pm 0.18^{\mathrm{c}, \mathrm{d}}$ & (49) \\
\hline $\mathrm{IL}-8^{\mathrm{a}}$ & $2,378 \pm 164$ & $2,380 \pm 189$ & $2,368 \pm 533$ & $(100)$ & $999 \pm 16^{\mathrm{c}, \mathrm{d}}$ & (42) \\
\hline $\mathrm{IL}-10^{\mathrm{a}}$ & $520 \pm 78$ & $1,880 \pm 29^{c}$ & $1,387 \pm 115^{\mathrm{c}, \mathrm{d}}$ & (74) & $582 \pm 74^{\mathrm{d}}$ & (31) \\
\hline IL-12p40a & $0.4 \pm 0.1$ & $19.5 \pm 0.7^{\mathrm{c}}$ & $16.6 \pm 4.0^{c}$ & (85) & $6.7 \pm 1.5^{\mathrm{c}, \mathrm{d}}$ & (34) \\
\hline IL-12p70a & $1.3 \pm 0.4$ & $48.6 \pm 1.8^{c}$ & $38.8 \pm 7.5^{\mathrm{c}}$ & $(80)$ & $10.5 \pm 1.3^{\mathrm{c}, \mathrm{d}}$ & (22) \\
\hline IL-13 $3^{\mathrm{b}}$ & $158 \pm 50$ & $652 \pm 127^{c}$ & $599 \pm 24^{c}$ & (92) & $120 \pm 68^{\mathrm{d}}$ & (18) \\
\hline $\mathrm{IFN}-\gamma^{\mathrm{b}}$ & $12.0 \pm 2.5$ & $38.8 \pm 4.6^{c}$ & $35.3 \pm 5.1^{\mathrm{c}}$ & (91) & $16.6 \pm 1.9^{\mathrm{d}}$ & (43) \\
\hline IP-10 & $159 \pm 37$ & $472 \pm 16^{c}$ & $315 \pm 44^{\mathrm{c}, \mathrm{d}}$ & (67) & $52 \pm 10^{\mathrm{c}, \mathrm{d}}$ & (11) \\
\hline MIP- $1 \beta^{a}$ & $704 \pm 168$ & $13,590 \pm 385^{\mathrm{c}}$ & $325 \pm 415$ & $(9)^{\mathrm{d}}$ & $2.8 \pm 0.9$ & $(0.02)^{\mathrm{c}, \mathrm{d}}$ \\
\hline $\mathrm{TNF} \alpha^{\mathrm{a}}$ & $3.1 \pm 0.5$ & $5,715 \pm 160^{c}$ & $4,740 \pm 431$ & $(83)^{c, d}$ & $1,650 \pm 367$ & $(29)^{\mathrm{c}, \mathrm{d}}$ \\
\hline
\end{tabular}

Cytokine secretion is expressed as ${ }^{a} \mathrm{ng} / \mathrm{mg}$ or ${ }^{b} \mathrm{pg} / \mathrm{mg}$ cell protein. ${ }^{c} \mathrm{p}<0.05$ versus control, ${ }^{\mathrm{d}} \mathrm{p}<0.05$ versus LPS treatment. IL, interleukin; IFN- $\gamma$, interferon- $\gamma$; IP-10, interferon-producing protein 10; MIP-1 $\beta$, macrophage inflammatory protein-1 $1 \beta$; TNF $\alpha$, tumor necrosis factor $\alpha$. Human adhered macrophage U937 cultures $(\mathrm{n}=3)$ were challenged with $10 \mu \mathrm{g} / \mathrm{ml}$ LPS supplemented with $10 \mu \mathrm{g} / \mathrm{ml}$ of the nutrient mixture, $2 \mu \mathrm{g} / \mathrm{ml}$ ibuprofen or vehicle for $24 \mathrm{~h}$. Conditioned culture media were collected and assayed with human cytokine microarray assay. Correlation analysis for ibuprofen (IBU) and nutrient mixture (NM) treatment: correlation coefficient $\mathrm{r}=0.6283, \mathrm{p}=0.0215$.

inflammation. Non-common cytokines for the mouse and macrophage model included the following. Cytokines unique to the mouse model were MCP-1 and GM-CSF, which increased with LPS, and VEGF that was unaffected by LPS. Cytokines unique to the macrophage model were interferonproducing protein 10 (IP-10) and macrophage inflammatory protein $1 \beta$ (MIP-1ß) which increased with LPS challenge and IL-8, which was unaffected by LPS.
Supplementation with the nutrient mixture reduced secretion of inflammatory cytokines by human adhered U937 macrophages in response to stimulation with bacterial lipopolysaccharide (Table II). Supplementation with ibuprofen demonstrated slight reduction in the secretion of inflammatory cytokines but significantly less than the effect shown by NM. The cytokines most responsive to anti-inflammatory supplementation were $\mathrm{TNF} \alpha(71 \%, \mathrm{p}<0.05$ with $\mathrm{NM}$ and 
Table III. Ranking of cytokine response to LPS challenge. ${ }^{a}$

\begin{tabular}{|c|c|c|c|c|}
\hline \multirow[t]{2}{*}{ Cytokine } & \multicolumn{2}{|c|}{ Mouse model } & \multicolumn{2}{|c|}{$\begin{array}{l}\text { Human U937 } \\
\text { macrophages }\end{array}$} \\
\hline & $\%$ of Control & Rank & $\%$ of Control & Rank \\
\hline IL-1ß & 2,065 & 6 & 2,194 & 4 \\
\hline IL-2 & 109 & 11 & 336 & 10 \\
\hline IL-4 & 111 & 10 & 359 & 9 \\
\hline IL-5 & 75 & 14 & $\mathrm{BDL}$ & NA \\
\hline IL-6 & $1,696,509$ & 1 & 1,914 & 5 \\
\hline IL-8 & ND & NA & 100 & 13 \\
\hline IL-10 & 2,670 & 5 & 361 & 8 \\
\hline IL-12p40 & 3,797 & 4 & 5,561 & 2 \\
\hline IL-12p70 & 602 & 7 & 3,633 & 3 \\
\hline IL-13 & 114 & 9 & 414 & 7 \\
\hline GM-CSF & 4,614 & 3 & ND & NA \\
\hline IFN- $\gamma$ & 80 & 13 & 322 & 11 \\
\hline IP-10 & ND & NA & 297 & 12 \\
\hline MCP-1 & 221,843 & 2 & ND & NA \\
\hline MIP-1ß & ND & NA & 510 & 6 \\
\hline $\mathrm{TNF} \alpha$ & 228 & 8 & 186,867 & 1 \\
\hline VEGF & 105 & 12 & ND & NA \\
\hline
\end{tabular}

${ }^{a}$ Comparison of mouse and human cultured macrophage models. BDL, below detection limit; NA, not applicable; ND, not determined. Abbreviations: as used in Tables I and II.

$17 \%, \mathrm{p}<0.05$ with IBU) and IL-12 (66\%, p $<0.05$ with NM and $15 \%, \mathrm{p}<0.05$ with IBU). NM suppressed LPS stimulation of IL- 6 secretion by $51 \%(\mathrm{p}<0.05)$ while IBU only reduced IL-6 secretion by $20 \%(\mathrm{p}<0.05)$. Still a statistical analysis of the effects of IBU and NM treatments revealed a significant correlation between the two treatments $(\mathrm{r}=0.6283, \mathrm{p}=0.0215)$. Thus the effects of ibuprofen and nutrient mixture on LPSinduced changes in cytokine secretion by human macrophages were strongly correlated.

Effects of individual nutrients on IL-10 secretion by human adhered U937 macrophages. Supplementation of individual flavonoids of the nutrient mixture at a concentration of $1.25 \mu \mathrm{M}$ had significantly reduced $(\mathrm{p}<0.05$ for all tested compounds versus LPS-only control) LPS-induced IL-10 secretion by human adhered U937 macrophages as shown in Fig. 2. IL-10 secretion was inhibited by EGCG to $47 \%$ $(\mathrm{p}=0.007)$ of that observed with LPS alone, to $44 \%(\mathrm{p}=0.004)$ by hesperetin, to $38 \%(\mathrm{p}=0.005)$ by naringenin, and to $31 \%$ $(\mathrm{p}=0.005)$ by quercetin. The differences between the effects of individual flavonoids did not reach statistical significance; however, quercetin produced the most pronounced inhibition of IL-10 secretion.

Effect of ibuprofen, the nutrient mixture and individual nutrients on prostaglandin E2 secretion. Prostaglandin E2 secretion by cultured macrophages was significantly (by 10.5-fold, p<0.001) stimulated by LPS challenge (Fig. 3). Supplementation with ibuprofen or the nutrient mixture dramatically reduced prostaglandin E2 secretion by stimulated macrophages. Ibuprofen inhibited PGE2 secretion by $95 \%$ $(\mathrm{p}=0.0001)$ and NM by $93 \%(\mathrm{p}=0.0001)$.

Individual components of the nutrient mixture had a variable effect on PGE2 secretion by U937 macrophages challenged with LPS as shown in Fig. 4. Supplementation of $10 \mu \mathrm{g} / \mathrm{ml}$ LPS with $30 \mu \mathrm{M}$ ascorbic acid increased PGE2 secretion by human adhered U937 macrophages to $220 \%$ $(\mathrm{p}=0.01)$ of that observed with LPS alone. The flavonoid-free basic nutrient mixture $(\mathrm{BM})$ at $25 \mu \mathrm{g} / \mathrm{ml}$, which contained ascorbic acid at a $30 \mu \mathrm{M}$ level, also increased PGE2 secretion, but less than ascorbic acid alone (to $169 \%, \mathrm{p}=0.06$ versus LPS alone). Apparently, some non-flavonoid NM components reduced the stimulating effect of ascorbate on PGE2 secretion

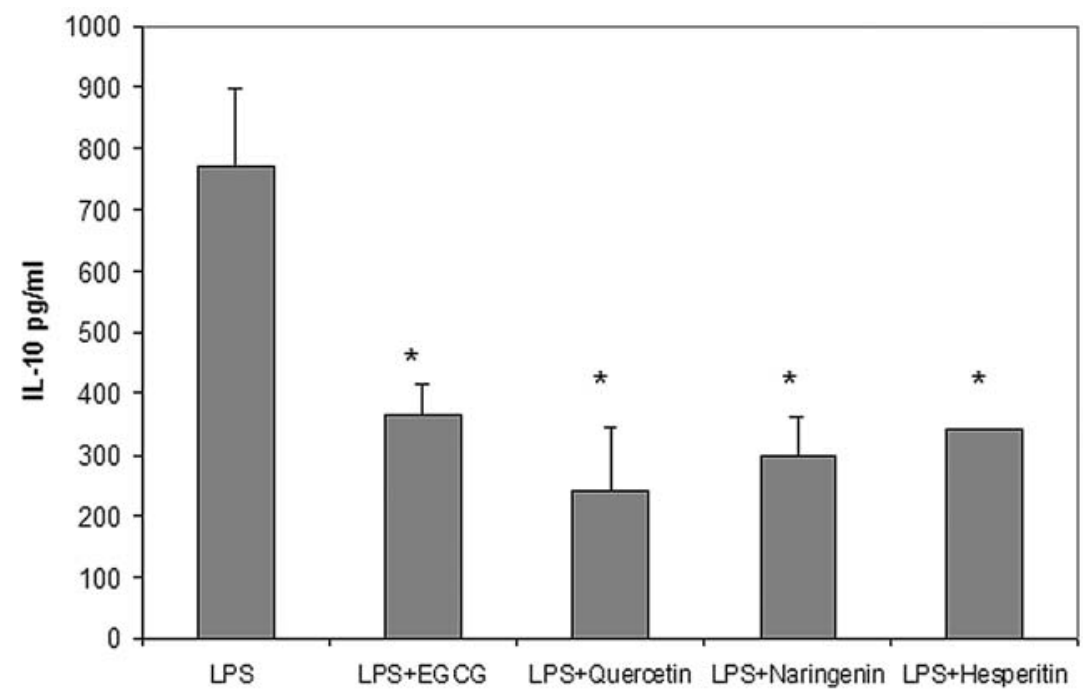

Figure 2. Effect of individual components of the nutrient mixture on IL-10 secretion by LPS challenged human U937 macrophages. Adhered macrophage cultures ( $\mathrm{n}=3$ ) were supplemented for $24 \mathrm{~h}$ with $10 \mu \mathrm{g} / \mathrm{ml}$ LPS and $1.25 \mu \mathrm{M}$ of individual flavonoids in $0.1 \%$ BSA/RPMI-1640 containing $40 \mathrm{nM}$ PMA. IL-10 levels in conditioned cell culture media were assayed by immunoassay. ${ }^{*} \mathrm{p}<0.01$ with respect to LPS group. 


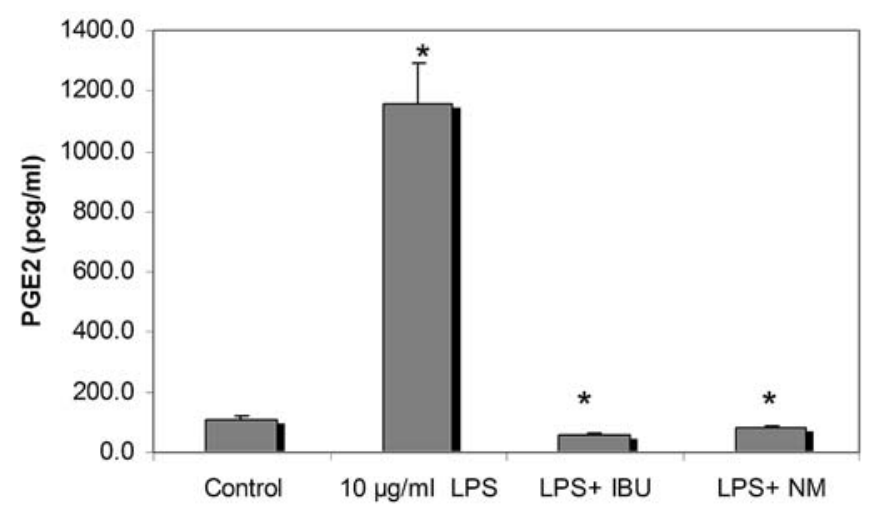

Figure 3. Effect of nutrient mixture or ibuprofen on prostaglandin E2 (PGE2) secretion by human adhered U937 macrophages. Adhered macrophage U937 cultures $(n=3)$ were incubated for $24 \mathrm{~h}$ with or without lipopolysaccharide (LPS) in the presence of $10 \mu \mathrm{g} / \mathrm{ml}$ of the nutrient mixture (NM), $2 \mu \mathrm{g} / \mathrm{ml}$ ibuprofen (IBU) or vehicle. Conditioned culture media were assayed for PGE2. ${ }^{*} \mathrm{p}=0.001$ with respect to the LPS group. by macrophages. BM stimulatory effect on PGE2 was slightly reduced by the addition of $20 \mu \mathrm{M}$ naringenin, which was still increased to $143 \%$ (although non-significantly at $\mathrm{p}=0.17$ ) of the LPS-only control.

Supplementation with $20 \mu \mathrm{M}$ EGCG in addition to BM and LPS inhibited PGE2 secretion to $51 \%(\mathrm{p}=0.13$ ) of LPS alone while the addition of $20 \mu \mathrm{M}$ hesperetin reduced PGE2 secretion by $91 \%(\mathrm{p}=0.02)$. The greatest inhibitory effects were noted upon supplementation with BM and $20 \mu \mathrm{M}$ quercetin (by $98 \%, \mathrm{p}=0.01$ ). Of interest, the combination of $5 \mu \mathrm{M}$ each of EGCG, hesperetin, naringenin, and quercetin with $\mathrm{BM}$, which practically comprises the complete content of NM, reduced PGE2 secretion by stimulated macrophages almost as effectively as the most potent flavonoid, quercetin, down to $6 \%$ of LPS alone ( $\mathrm{p}<0.05$ versus LPS). Thus, despite the fact that various NM components stimulated PGE2 secretion by macrophages, NM produced greater inhibition of PGE2 secretion ( $94.4 \%$ inhibition) than the calculated

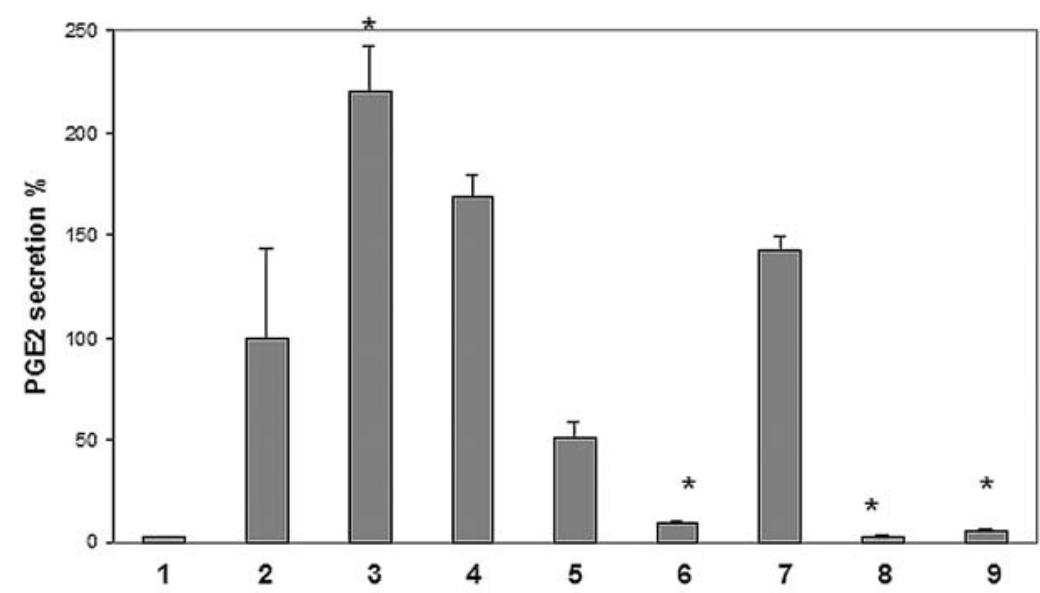

Figure 4. Effect of individual nutrient components on prostaglandin E2 secretion by human adhered U937 macrophages. Experimental conditions were as described in Fig. 3. 1, no LPS (control); 2, LPS $10 \mu \mathrm{g} / \mathrm{ml} ; 3$, LPS $+30 \mu \mathrm{M}$ ascorbic acid; 4, LPS + $25 \mu \mathrm{g} / \mathrm{ml}$ flavonoid-free nutrient mixture (BM); 5, LPS + $\mathrm{BM}+20 \mu \mathrm{M}$ epigallocatechin gallate (EGCG); 6, LPS + BM + $20 \mu \mathrm{M}$ hesperitin (HP); $7, \mathrm{LPS}+\mathrm{BM}+20 \mu \mathrm{M}$ naringenin $(\mathrm{NR}) ; 8, \mathrm{LPS}+\mathrm{BM}+20 \mu \mathrm{M}$ quercetin (Q); 9, LPS + BM $+5 \mu \mathrm{M} \mathrm{EGCG}+5 \mu \mathrm{M} \mathrm{NR}+5 \mu \mathrm{M} \mathrm{HP}+5 \mu \mathrm{M}$ Q. ${ }^{*} \mathrm{p}<0.05$ with respect to the LPS group.

A

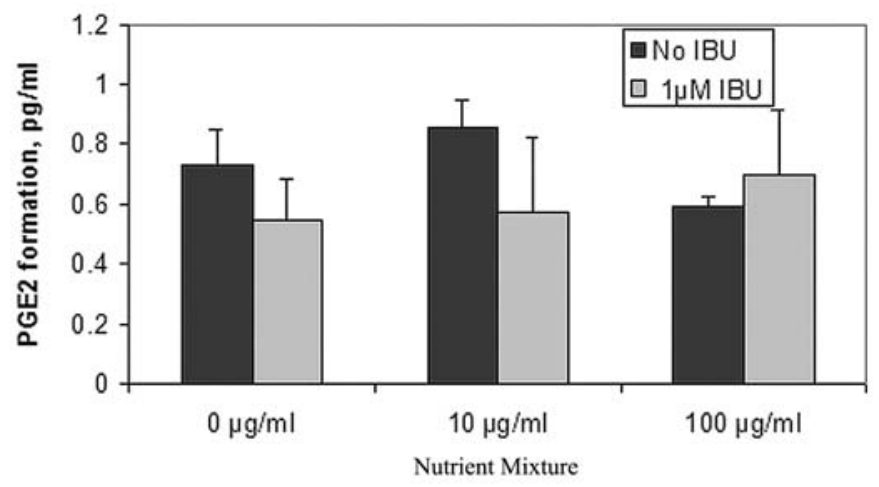

B

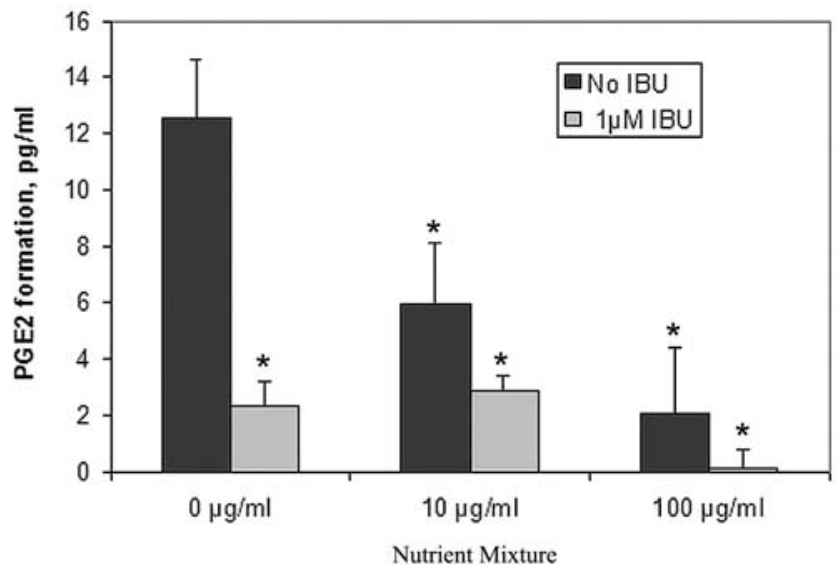

Figure 5. Effect of the nutrient mixture (NM) on COX enzymatic activity. Adhered U937 macrophage cultures were activated with $10 \mu \mathrm{g} / \mathrm{ml}$ LPS for $24 \mathrm{~h}$ (B) or not (A). Cell cultures were washed of LPS and pre-incubated with 10 or $100 \mu \mathrm{g} / \mathrm{ml} \mathrm{NM}$ in the presence (open bars) or absence (closed bars) of $1 \mu \mathrm{M}$ ibuprofen (IBU) for $15 \mathrm{~min}$ in BSA-supplemented medium. Arachidonic acid was added to the same media at $15 \mu \mathrm{M}$ for another 15 min at $37^{\circ} \mathrm{C}$, and PGE2 formation in conditioned media was assayed immunochemically. (B) ${ }^{*} \mathrm{p}<0.05$ with respect to the LPS group; correlation of trend, $\mathrm{r}=0.7509$ and $\mathrm{p}=0.0318$. 
A

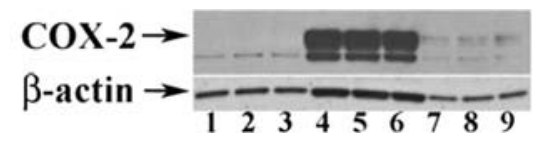

B

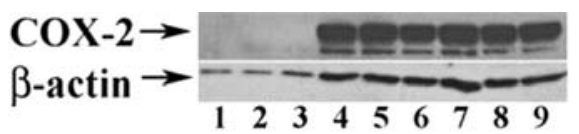

C

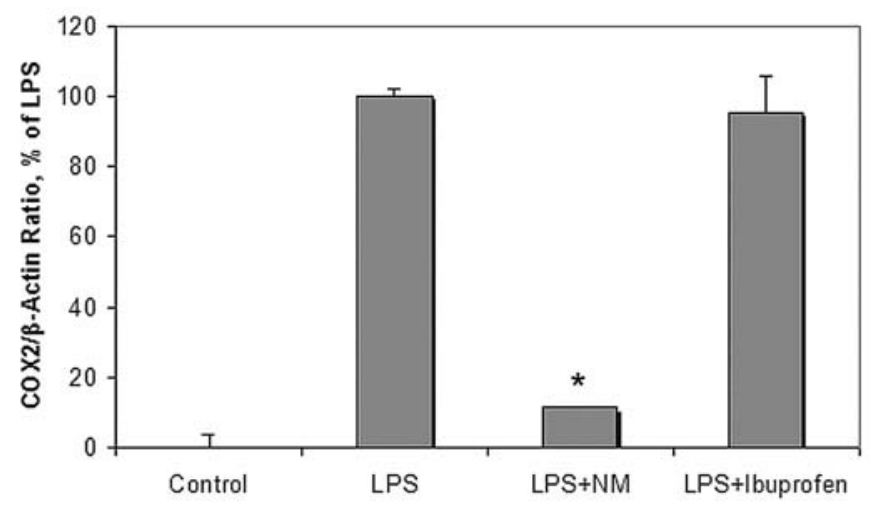

Figure 6. Effect of nutrient mixture (NM) and ibuprofen (IBU) on COX2 protein expression in human adhered macrophages. Experimental conditions were as described in Materials and methods. (A) 1-3, unsupplemented control; 4-6, $10 \mu \mathrm{g} / \mathrm{ml}$ LPS; and 7-9, LPS + $10 \mu \mathrm{g} / \mathrm{ml} \mathrm{NM}$. (B) $1-3$, unsupplemented control; 4-6, $10 \mu \mathrm{g} / \mathrm{ml} \mathrm{LPS}$; and 7-9, LPS $+2 \mu \mathrm{g} / \mathrm{ml} \mathrm{IBU}$. (C) Stained band density in gel images (A and B) were measured using Scion Image software and expressed as COX $2 / \beta$-actin ratio (percentage of the LP- only value). ${ }^{*} \mathrm{p}=0.005$ with respect to the LPS group.

combined effects of individually tested compounds $(48.5 \%$ inhibition, assuming linear dose-dependent effects for individual flavonoids when tested in combination with the basic nutrient mixture.)

Effect of ibuprofen and the nutrient mixture on COX-2 enzymatic activity. Direct effects of NM on COX enzymatic activity were tested in cultured U937 macrophages, stimulated or not with LPS. The Western blot assay revealed relatively low levels of COX-1 protein expression on cell membranes of non-stimulated macrophages (data not shown), whereas COX-2 protein was virtually undetectable (Fig. 6). Stimulation of macrophages with LPS dramatically increased COX-2 protein cellular expression (Fig. 6); however, levels of COX-1 protein were not affected by LPS challenge (data not shown). According to these results, COX enzymatic activity in nonstimulated cells belongs mainly to constitutive COX-1 isoenzyme, whereas in LPS-stimulated macrophages, the COX-2 isoenzyme is prevalent. As shown in Fig. 5A, $1 \mu \mathrm{M}$ ibuprofen had a slight inhibitory effect on COX-1 activity, although statistically non-significant at this concentration. NM did not influence COX-1 activity at dosages up to $100 \mu \mathrm{g} / \mathrm{ml}$ nor did it alter the effect of ibuprofen when used in combination (Fig. 5A). COX-2 enzymatic activity was directly inhibited by NM in a dose-dependent (correlation of trend, $\mathrm{r}=0.7509, \mathrm{p}=0.0318$ ) manner, as shown in Fig. 5B. PGE2 formation was inhibited by $53 \%(p=0.02)$ in the presence of $10 \mu \mathrm{g} / \mathrm{ml} \mathrm{NM}$ and by $84 \%(\mathrm{p}=0.005)$ at $100 \mu \mathrm{g} /$ $\mathrm{ml}$ NM. IBU enhanced inhibition of PGE2, reducing the PGE2 level to $23 \%(\mathrm{p}=0.002)$ of the LPS group at $10 \mu \mathrm{g} / \mathrm{ml}$ $\mathrm{NM}$ and to $1 \%(\mathrm{p}=0.001)$ at $100 \mu \mathrm{g} / \mathrm{ml} \mathrm{NM}$.

Effect of the nutrient mixture on $\mathrm{COX}-2$ and $\mathrm{COX}-1$ protein expression by human adhered U937 macrophages. As shown in Fig. 6A, the nutrient mixture suppressed COX-2 protein expression by human adhered U937 macrophages (Western blot analysis). Expression of COX-1 protein was detected in non-stimulated U937, but its levels did not change under cell stimulation with LPS (data not shown). Ibuprofen had no apparent effect on COX-2 protein expression (Fig. 6B). As shown in Fig. 6C, NM inhibited LPS-induced COX-2 expression by $88 \%(\mathrm{p}<0.0001)$ in contrast to ibuprofen which had an insignificant effect on COX-2 expression (by 5\%, $\mathrm{p}=0.5)$.

Effect of the nutrient mixture on COX-2 and inflammatory cytokine gene expression. As shown in Fig. 7, the nutrient mixture suppressed COX-2 and inflammatory cytokine transcription by reducing the level of mRNA in human adhered U937 macrophages (real-time PCR with TagMan detection system). Fig. 7A provides a representative amplification plot for RT-PCR. As shown in Fig. 7B, exposure of human adhered U937 macrophages to NM inhibited COX-2 mRNA by $93 \%(p=0.02)$ of that noted with LPS alone. NM profoundly inhibited mRNA levels of the following inflammatory mediators: IL-1ß (98\%, p<0.0001), IL-6 (96\%, $\mathrm{p}=0.05), \operatorname{IL} 12 \mathrm{p} 40(89 \%, \mathrm{p}=0.15)$ and $\mathrm{TNF} \alpha(95 \%, \mathrm{p}=0.06)$ (Fig. 7C-F).

Effect of the nutrient mixture on nuclear factor $\kappa \beta$ activation in human cultured macrophages. The nutrient mixture suppressed $\mathrm{NF} \kappa \beta$ activation in human cultured macrophages by $45 \%$, $\mathrm{p}<0.05$, as shown in Fig. 8.

\section{Discussion}

A complex biochemical pathway is set in motion once stimulated by injury that leads to the production of cytokines and other inflammatory mediators. The discovery of endogenous molecules involved in the inflammatory process, such as inflammatory cytokines, provides promising targets for controlling inflammation. To investigate the effect of the nutrient mixture on cytokines, we utilized a model of acute systemic inflammation in mice challenged with bacterial LPS; we found that supplementation of BALB/c mice with NM significantly reduced overexpression of blood plasma inflammatory cytokines. We also found that supplementation with the nutrient mixture significantly reduced secretion of inflammatory cytokines in vitro by human adhered U937 macrophages in response to stimulation with bacterial LPS. Though the relative cytokine response to LPS challenge in the mouse model varied from the human macrophage cell model, IL-1ß, IL-6, IL-10 and IL-12 were increased greatly in both models. To elucidate the role played by individual components of the nutrient mixture, we investigated the individual effects of EGCG, quercetin, naringenin and hesperitin on IL-10 secretion by human adhered U937 macrophages. Though all 
A

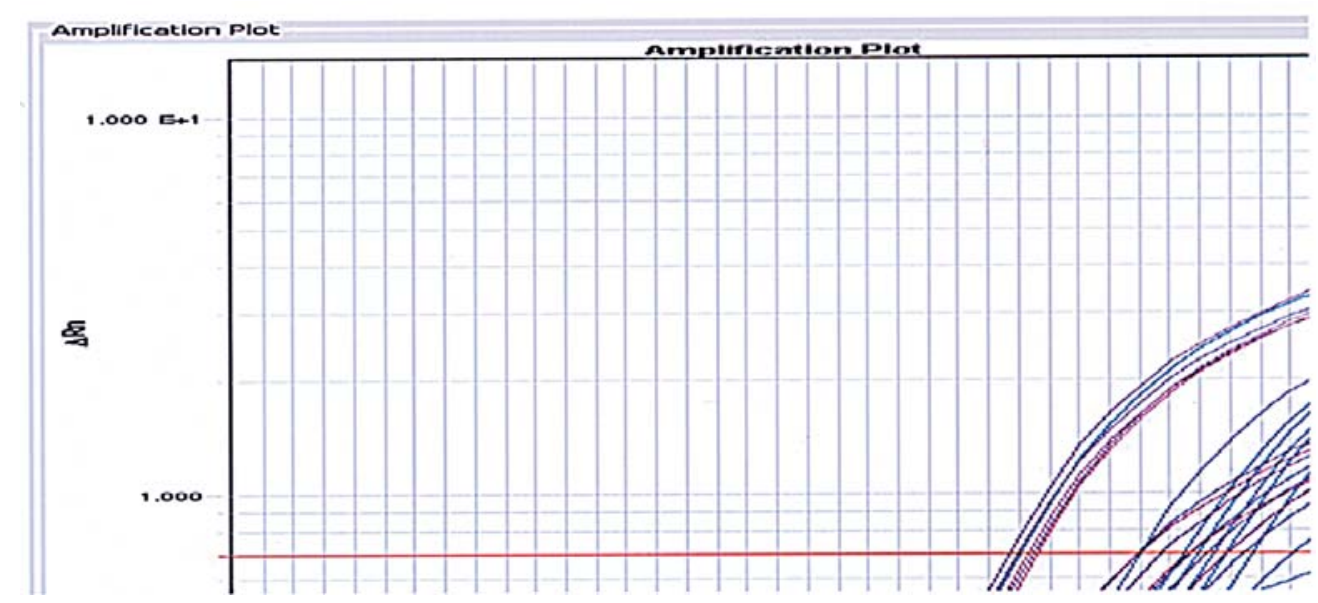

B

C

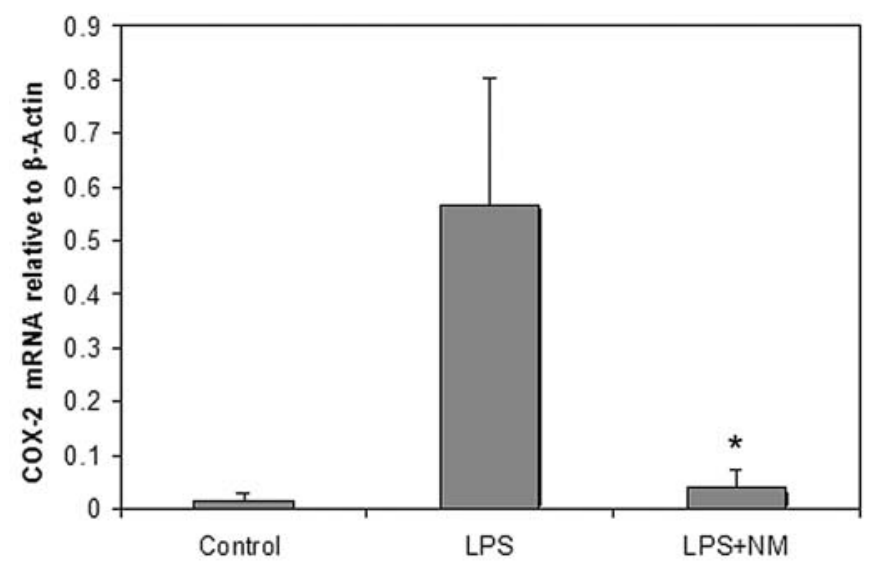

D

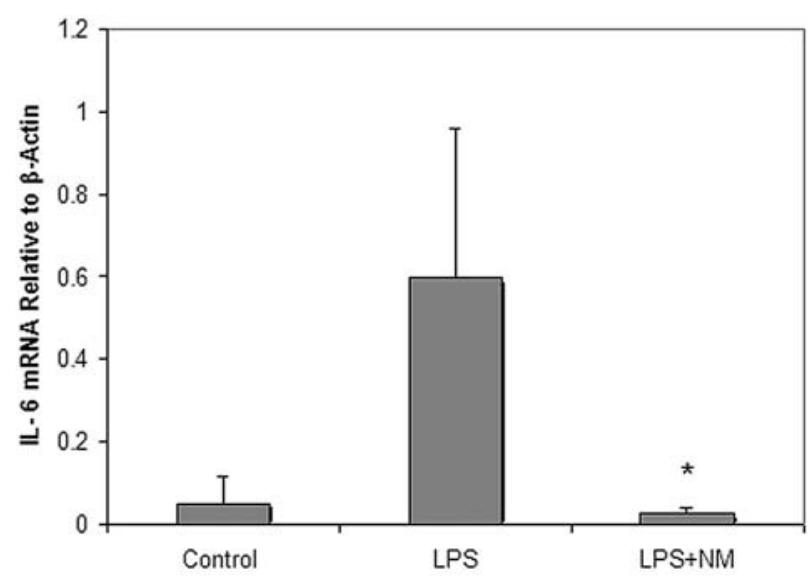

$\mathbf{F}$

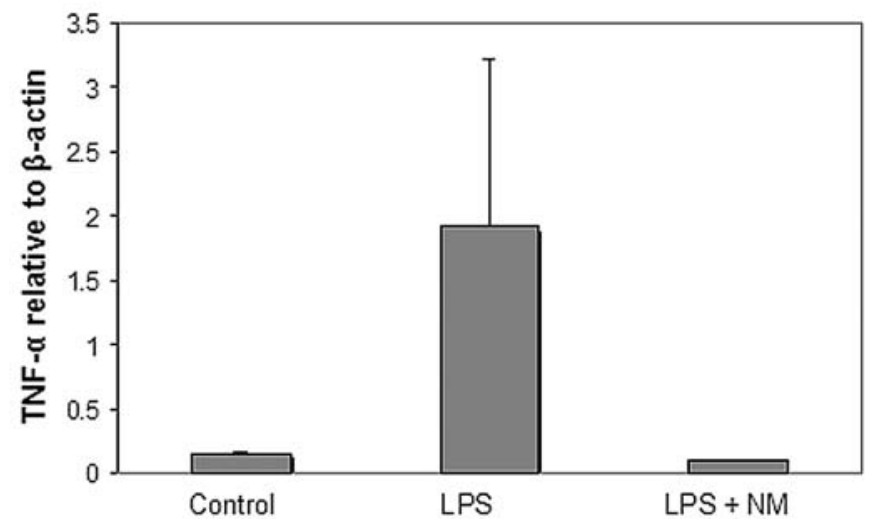

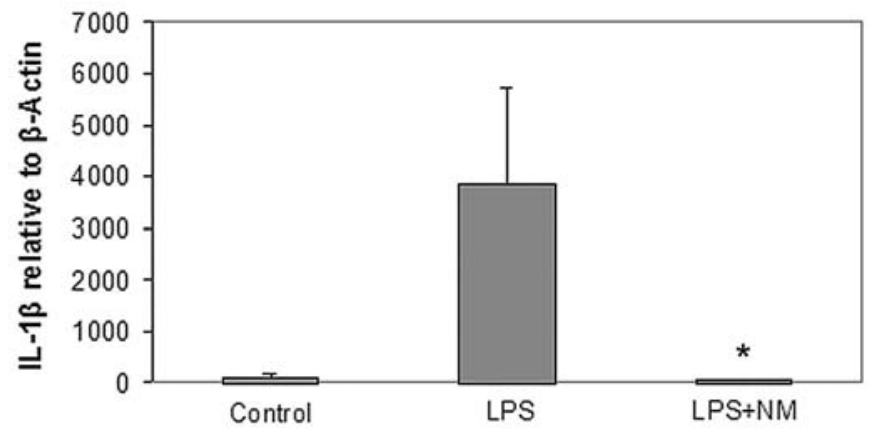

$\mathbf{E}$

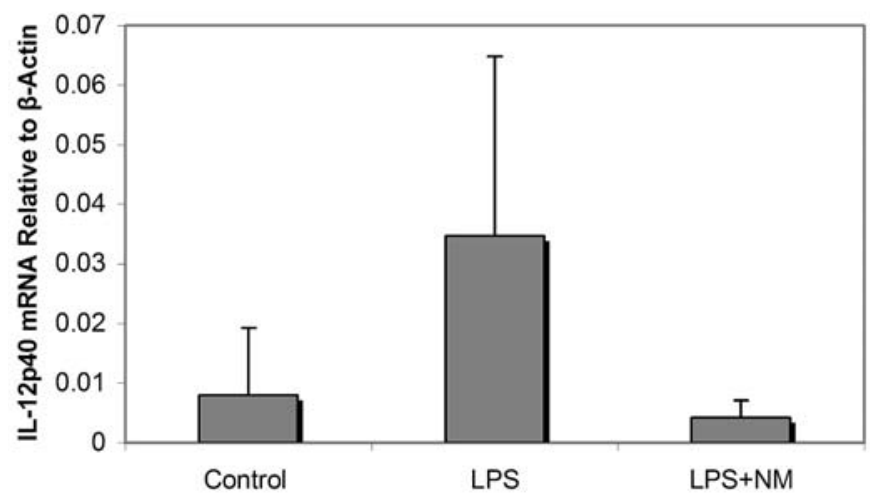

Figure 7. Effect of nutrient mixture (NM) on COX-2 and inflammatory cytokine transcription by reducing the level of mRNA in human adhered U937 macrophages (real-time PCR with TagMan detection system). Experimental conditions were as described in Materials and methods. (A) Representative example of amplification plot for RT-PCR. Effect of NM on (B) COX-2, (C) IL-1B, (D) IL-6, (E) IL-12p40 and (F) TNF $\alpha$ mRNA. ${ }^{*} \mathrm{p}<0.05$ with respect to the LPS group. 


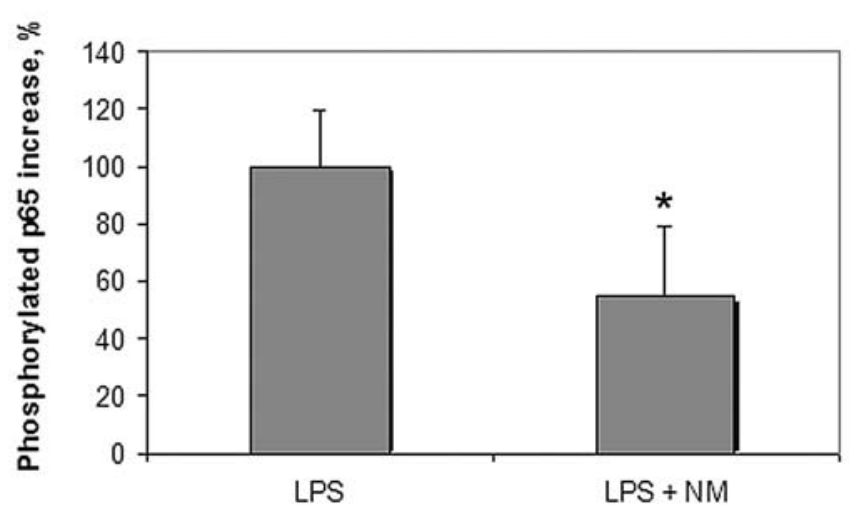

Figure 8. Effect of nutrient mixture (NM) on nuclear factor $\kappa \beta$ activation in human cultured macrophages. Human adhered U937 macrophages were challenged with $10 \mu \mathrm{g} / \mathrm{ml}$ LPS for $20 \mathrm{~min}$ after a 2 -h pre-incubation with or without $10 \mu \mathrm{g} / \mathrm{ml}$ NM. Levels of phosphorylated p65 were determined in cell protein extracts by ELISA. ${ }^{*} \mathrm{p}<0.05$ with respect to the LPS group.

tested nutrients suppressed IL-10 secretion, quercetin was found to be the most effective suppressor of IL-10 secretion.

To probe further into the anti-inflammatory effect of the nutrient mixture along the arachidonic pathway, we also studied its effect on PGE2 and compared it to that shown by ibuprofen. Arachidonic acid is released from traumatized tissues and is transformed into prostoglandins and thomboxanes through the action of COX (15). Prostoglandins, short-lived localized hormones released by cells during tissue, chemical or traumatic injury, can induce fever, inflammation and pain once they are present in the intercellular space $(16,17)$.

In studying the effect of the nutrient mixture and ibuprofen on PGE2 formation by LPS-induced human adhered U937 macrophages, both ibuprofen and the nutrient mixture were found to profoundly reduce PGE2 secretion by the stimulated macrophages. Individual NM components and combinations were found to have variable effects on PGE2 secretion, with enhanced PGE2 secretion in the presence of ascorbic acid, which was dramatically decreased in the presence of quercetin greater than hesperetin and EGCG. The nutrient combination, however, had a greater inhibitory effect on PGE2 secretion by stimulated macrophages than expected from the additive effect of individual compounds. This suggests synergistic activity of the different nutrients, indicating possible involvement of different molecular mechanisms. Further analyses revealed at least two different mechanisms involved: NM-driven reduction of COX-2 protein expression in addition to the direct inhibition of COX-2 enzymatic activity.

COX enzymes were the logical mediators to investigate, as aspirin has been shown to reduce inflammation by irreversibly disabling the COX enzymes so that they no longer produce the inflammatory prostoglandins and thomboxanes (18). COX enzymes are found in two forms in the human body: COX-1, a constitutive enzyme that normally protects the gastrointestinal mucosa; and COX-2 which is activated by tissue damage and is considered to be an inducible enzyme because it exists during injury only $(15,19-21)$. Due to the gastrointestinal effects associated with such anti-inflammatory medications as aspirin and the nonselective NSAIDS, which block both COX-1 and COX-2, researchers are investigating agents that block COX-2 selectively and thereby limit the complications of gastritis and ulcers that are common with long-term use.

Based on the findings cited in the literature on COX enzymes, we investigated the effects of the nutrient mixture and ibuprofen on COX-2 and COX-1 protein expression. We found that the nutrient mixture profoundly $(88 \%, \mathrm{p}<0.0001)$ suppressed LPS-induced COX-2 expression but had no effect on COX-1 expression. Ibuprofen had a minimal insignificant effect on COX-2 protein expression; its effects were limited to direct inhibition of COX-1 and -2 enzymatic activity. We also found that the nutrient mixture suppressed COX-2 and inflammatory cytokine transcription by reducing mRNA levels in human adhered U937 macrophages.

In addition to the role of COX enzymes, additional pathways have been discovered that are more complex and associated with persistent or chronic inflammation. In addition to roles in other physiological processes, the NFK $\beta$ protein acts as a switch to turn inflammation on and off in the body. $\mathrm{NF} \kappa \beta$ is able to detect noxious stimuli, such as infectious agents, free radicals and other cellular injuries and turn on the particular genes that lead to production of inflammatory cytokines $(3,4)$. The NFK $\beta$ proteins are localized in the cytoplasm of the cell and are normally bound to a family of inhibitory proteins known as Iк $\beta$ proteins $(22,23)$. A variety of cytokine stimuli such as trauma, viral infections, ultraviolet radiation, free radicals and $\mathrm{TNF} \alpha$ and IL- $1 \beta$ can degrade the I $\beta$ resulting in the nuclear translocation of $N F \kappa \beta(3,4)$. A

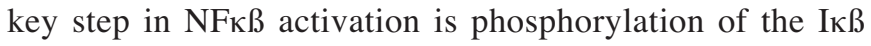
proteins and unbinding of the NFкß. NFкß proteins then translocate to the nucleus, where they bind to target genes to activate gene expression for a host of inflammatory molecules. These include proinflammatory cytokines such as IL-1ß, TNF $\alpha$, IL- 6 and IL-18 which are involved in the initiation and amplification of the inflammatory process, protein kinases that regulate the expression of other target genes necessary for maintaining the inflammatory state, various adhesion molecules and chemokines (4).

Research into potential inhibitors which are able to prevent $N F \kappa \beta$ activation and hence reduce the inflammatory process is focusing on a new generation of anti-inflammatory medications. The identification of NFKß as a critical switch that turns on inflammation has profound implication for therapeutic manipulation of regulatory circuits controlling the inflammatory process, regardless of its causes. Therefore, we also investigated the effect of the nutrient mixture on $\mathrm{NF \kappa} ß$ activation in human cultured macrophages. The results demonstrated that NM suppressed activation of $N F \kappa \beta$, indicating an involvement of the NFKß-controlled signal transaction pathway.

In conclusion, the tested combination of nutrients demonstrated strong inhibitory effects on experimental inflammation by reducing expression of inflammatory mediators by interfering with multiple responsible molecular mechanisms.

\section{Acknowledgements}

The study was funded by the Dr Rath Health Foundation (Plantation, FL, USA), a non-profit organization. 


\section{References}

1. Plutzky J: Inflammatory pathways in atherosclerosis and acute coronary syndromes. Am J Cardiol 88: 10K-15K, 2001.

2. Jatta K, Wagsater D, Norgren L, Stenberg B and Sirsjo A: Lipopolysaccharide-induced cytokine and chemokine expression in human carotid lesions. J Vasc Res 42: 266-271, 2005.

3. Opal SM and DePalo VA: Anti-inflammatory cytokines. Chest 117: 1162-1172, 2000.

4. Wong MM and Fish EN: Chemokines: attractive mediators of the immune response. Semin Immunol 15: 5-14, 2003

5. Lawrence T, Gilroy DW, Colville-Nash PR and Willoughby DA: Possible new role for NF-kappa B in the resolution of inflammation. Nat Med 7: 1291-1297, 2001.

6. Gilroy DW, Colville-Nash PR, Willis D, Chivers J, Paul-Clark MJ and Willoughby DA: Inducible cyclooxygenase may have antiinflammatory properties. Nat Med 5: 698-701, 1999.

7. Ahmed S, Wang N, Lalonde M, Goldberg VM and Haqqi TM: Green tea polyphenol epigallocatechin-3-gallate (EGCG) differentially inhibits interleukin-1 beta-induced expression of matrix metalloproteinase- 1 and -13 in human chondrocytes. $\mathrm{J}$ Pharmacol Exp Ther 308: 767-773, 2004.

8. Jung WJ and Sung MK: Effects of major dietary antioxidant on inflammatory markers of RAW 264.7 macrophages. Biofactors 21: 113-117, 2004.

9. Kawaguchi K, Kikuchi S, Hasunuma R, Maruyama H, Hoshikawa T and Kumazawa Y: A citrus favonoid hesperidin suppresses infection-induced endotoxin shock in mice. Biol Pharm Bull 27: 679-683, 2004.

10. Fiebich BL, Lieb K, Kammerer N and Hüll M: Synergistic inhibitory effect of ascorbic acid and acetylsalicylic acid on prostaglandin E2 release in primary rat microglia. J Neurochem 86: 173-178, 2003.

11. Kawaguchi K, Kikuchi S, Hasunuma R, Maruyama H, Ryll R and Kumazawa Y: Suppression of infection-induced endotoxin shock in mice by a citus flavanone naringin. Planta Med 70: 17-22, 2004.
12. Farrell S: Toxcity, acetaminophen. emedicine toxicity, acetaminophen $2006 \mathrm{http}: / / \mathrm{emedicine.com/emerg/} \mathrm{topic819.htm.}$

13. Cooke JP and Dzau VJ: Nitric oxide synthase: Role in the genesis of vascular disease. Annu Rev Med 48: 489-509, 1997.

14. Uhlmann D, Scommotau SH, Witzigmann H and Spiegel HU: Exogenous L-arginine protects liver microcirculation from ischemia reperfusion injury. Eur Surg Res 30: 175-184, 1998.

15. Fitzgerald GA: Coxibs and cardiovascular disease. N Engl J Med 351: 1709-1711, 2004.

16. Ghosh S, May MJ and Kopp EB: NF-кB and Rel proteins: evolutionarily conserved mediators of immune responses. Annu Rev Immunol 16: 225-260, 1998.

17. Talalay $P$ and Talalay $P$ : The importance of using scientific principles in the development of medicinal agents from plants. Acad Med 76: 238-247, 2001.

18. Vane JR: Inhibition of prostaglandin synthesis as a mechanism of action for aspirin-like drugs. Nat New Biol 231: 232-235, 1971.

19. Mix KS, Mengshol JA, Benbow U, Vincenti MP, Sporn MB and Brinckerhoff CE: A synthetic triterpenoid selectively inhibits the induction of matrix metalloproteinases 1 and 13 by inflammatory cytokines. Arthritis Rheum 44: 1096-1104, 2001.

20. Rahusen FTJ, Weingold PS and Almekinders LC: Nonsteroidal anti-inflammatory drugs and acetaminophen in the treatment of an acute muscle injury. Am J Sports Med 32: 1856-1859, 2004.

21. Warner TD, Giuliana F, Vojnovic I, Bukasa A, Mitchell JA and Vane JR: Nonsteroid drug selectivities for cyclooxygenase-1 rather than cyclooxygenase- 2 are associated with human gastrointestinal toxicity: a full in vitro analysis. Proc Natl Acad Sci USA 96: 7563-7568, 1999.

22. Baldwin AS: The NF- $\kappa$ B and IкB proteins: new discoveries and insights. Annu Rev Immunol 14: 649-681, 1996.

23. Vane $\mathbf{J}$ and Botting R: Inflammation and the mechanism of action of anti-inflammatory drugs. FASEB J 1: 89-96, 1987. 